\title{
The role of the community nurse on health committees
}

\author{
V M Taylor, M Cur student,Department of Nursing, RAU \\ E J Gross, D Cur \\ S D Roos, D Cur,Senior Lecturer, Department of Nursing, RAU
}

\section{Abstract}

With the changes in health care occurring in South Africa, new functions concerning the community nurse are being presented. The goal of the study was to explore and describe the role of the community nurse in health committees.

An explorative, descriptive design was used and the empirical part was undertaken within the context of a metropolitan local authority. After conducting a literature study, six major roles of the community nurse on health committees were identified. After that a questionnaire was presented to community nurses to explore and describe their perceptions about the role of the community nurse on health committees. An interview schedule based on the literature study was drafted for presentation to selected members of health committees. Lastly guidelines describing the role of the community nurse on health committees were developed based on the findings of the study.

\section{Opsomming}

Met die veranderinge wat plaasvind in die Suid-Afrikaanse gesondheidsorg word nuwe funksies voorgestel wat betrekking het op die gemeenskapsverpleegkundige. Die doel van die studie was om een van die relatiewe nuwe funksies van die gemeenskapsverpleegkundige, naamlik die rol van die gemeenskapsverpleegkundige in gesondheidskomitees, te verken en te beskryf.

'n Verkennende beskrywende ontwerp is benut en die empiriese werk is uitgevoer binne die konteks van ' $n$ metropolitaanse plaaslike owerheid. Nadat ' $n$ literatuurstudie uitgevoer is, is ses hoofrolle van die gemeenskapsverpleegkundige in gesondheidskomitees, geïdentifiseer.'n Vraelys is hierna aan gemeenskapsverpleegkundiges voorgelê om hulle persepsies van die rol van die gemeenskapsverpleegkundige in gesondheidskomitees te verken en beskryf.'n Onderhoudsskedule gegrond op die literatuurstudie is opgestel vir gebruik by geselekteerde lede van gesondheidskomitees. Laastens is riglyne neergelê wat die rol van die gemeenskapsverpleegkundige in gesondheidskomitees beskryf.

\section{Introduction}

The researcher has worked in the community for many years as a community nurse. She has been involved in community development through interaction and the initiation of various educational, self-help and support groups. These endeavours are seen as part of the broad role of the community nurse, and encouragement was received from policy makers in different settings when community needs had to be met. Health committees are being developed to promote community participation at grass root levels in decision-making regarding health policy and service. The community nurse is equipped through his/her training and experience to be a valuable member of a health committee. The community nurse knows the area he/she is working in, knows the local health problems and community leaders and should realize the value of the development of health committees with the grass root contribution of the community to the solving of local health problems.

\section{The role of the community nurse on health committees}

Nurses have always claimed to have a role in health care planning and "the vital role that the community nurse plays with regard to achieving optimal health for the community is widely acknowledged" (Dennill, King, Lock \& Swanepoel, 1995:103). The new dispensation in health care in South Africa presents the community nurse with challenges and opportunities to contribute to the health system and strive for quality health care built on the primary health care principles stipulated in the Declaration of Alma Ata (World Health Organization, 1978). One of these principles is community participation.

A feature of community participation indicated in the Declaration of Alma At (1978) and more recently in the White Paper for Health Transformation is the establishment of health committees in local authority areas, some of which are al- 
ready operating. Community nurses are pivotal in the establishment of health committees. They apparently have a role to play on health committees because of the nature of their training and their strategic positions in the communities they serve. They also have access to statistics and community profiles and because of this they can be of value to these committees. This has been endorsed by Dennill, et al. (1995:103) who state that the community nurse plays a vital role regarding improvement of the health of the community. The idea of helping communities identify health priorities in their community is part of the role of the community nurse. The community nurses must help facilitate a partnership between the health care workers and the community (White Paper for the Transformation of the Health System in South Africa, 1997:3334). According to the same document the aims of the health committees are that, via decentralized management of health care, everyone should have access to quality health care (Oerman, 1994:215).

Health norms must be identified at local level by health committees and national norms should be established. An interface between the community and the health system needs to be developed at local level (White Paper for Transformation of the Health System in South Africa, 1997:35; ANC, 1994:59-60). The community nurse slots in here as a link, having contact with both the community (including the health committee) and the health care providers. Dennill, et al. (1995:8) states that change will have to occur so that the capacity of the community is increased before real change will be realized. The community, via the health committee, will take responsibility for their own health needs and find solutions to those needs, "assessing their own needs, making decisions, planning, implementing and even evaluating the care they receive" (Dennill, et al. 1995:8). The health committee is a novel feature of primary health care, providing a platform for the community to participate in the health service in the area. The health committee help determine local priorities as well as being involved with staff selection and facilitation of the budget (ANC, 1994:60; White Paper for the Transformation of the Health System in South Africa, 1997:3334). The health committee will be able to send a representative to inter-sectoral committee meetings of the District and this way health needs in each area will be able to be addressed (White Paper on the Transformation of the Health System in South Africa, 1998:35).

To obtain community participation, decentralization of the management of health care was necessary and the country needed to be divided into small areas of operation. To divide the country into manageable geographical areas, the District Health Model which is applied in the United Kingdom was introduced and a similar system is presently being implemented as the core of the entire health strategy (Owen, 1996:18). The health services of a District are responsible to serve a well defined population within a clearly delineated and functionally coherent area (Owen, 1996:18). Falling under the District will be structures such as clinics, health centres, hospitals and health committees. The community nurse will function in the community in a certain area of the District. He/she will move into various roles to meet the needs of the individuals and groups in the area he/she serves (White Paper for the Transformation of Health System in South Af- rica, 1997-30-37).

The community nurses have always been required to possess a wide range of skills and attributes stretching well beyond the ability to care for the sick. But in today's changing health care scenario, where the paradigm is shifting from illness to wellness, in South Africa, even more is being demanded of them, and the scope of their roles has widened even further (Dennill, et al. 1995:21; Trofino, 1997:50-52). Nurses are challenged to contribute to the reconstruction of the health services in South Africa. What is expected of them has been precipitated by the reconstruction process and caused role confusion amongst community nurses (Poggenpoel, 1996:12). When community nurses interpret their role correctly, and implement action which is within their scope of practice, they may encounter resistance from other groups within the health care arena, because they are performing duties not previously associated with them (Lauffer, 1978:105). One such duty is that of group consultant (Dennill, et al. 1995:21). A significant problem regarding the role of community nurses on health committees specifically exists and therefore warrant an indepth research.

The question that arises from this problem and needs to be answered is "What role is the community nurse playing and what role should he/she be playing on health committees?"

In order to address this question the researcher set the following objectives namely to:

- explore and describe the role the community nurse is and should be playing on health committees, and

- develop guidelines to describe the role of the community nurse on health committees.

\section{Research design and method}

The design was exploratory and descriptive in nature. This design was utilised because the purpose was to explore and describe the role of the community nurse on health committees in order to write guidelines as to what the community nurse on health committees should be. The research was contextual, because the role of the community nurse on health committees in one specific metropolitan local authority area in the Gauteng Province in South Africa where the researcher was working, was investigated.

A questionnaire was developed after a literature study (phase one) was done. This questionnaire was presented to community nurses where the researcher was working to explore their perceptions as to what the role of the community nurse on health committees is and should be. The questionnaire, with face and content validity secured, consisted of eight sections covering demographic data, health committees as such, policy/ legislation, education/in-service training of nurses, community involvement, beliefs/values, the role of the nurse on health committees and a section covering general contributions from the respondents. The target population was a group of community nurses working with the researcher at a metropolitan local authority on the East Rand. The group consisted of 53 community nurses, all female, employed by the said metropolitan local authority. Those who met the set criteria were 41 in number of whom 38 were available when the researcher 
handed the questionnaires over in person after an in-service training session. The questionnaires were completed within 15 minutes. Hundred percent returned the completed questionnaire. The data was analysed manually by the researcher in the form of percentages and frequencies. The open ended question was analysed using Tesch's method of data-analysis (in Creswell, 1994:155).

Furthermore five health committees at the local authority concerned were included in the study as significant role players. Individual health committees comprised of six members on average and they are elected by the community. Individual interviews were conducted with a purposive sample of four individual members of these health committees (phase 2) to explore their perceptions as to what the role of the community nurse on health committees is and should be. No more members could be involved due to poor telecommunication systems, taxi violence and adverse weather conditions. A central question was asked during the individual interviews namely:

"What do you believe is and should be the role of the community nurse on health committees".

Data was captured on a tape recorder with the verbal permission of the respondents and analysed using Tesch's (in Creswell 1994:155) method.Trustworthiness was ensured utilising the strategy as described by Lincoln \& Guba, (1985:306) Lastly guidelines describing the role of the community nurse on health committees were developed by utilising the data obtained from the various sources.

\section{Definitions}

\section{Community nurse}

For the purposes of this study the community nurse is a professional registered nurse who works in the community, for a local authority, with additional qualifications in community nursing science. involve the community with solving problems in their area in a cost effective manner, taking preventative measures and participating in health policy and service. They have an advocacy, advisory and co-ordination role to play (Ferrinho, Rob Cornieljie \& Rex, 1993:14; Oakley 1989:5; ANC, 1994:61; White Paper for the Transformation of the Health System in South Africa, 1997:34-35).

\section{Findings on the role of the community nurse on health committees}

\section{Community nurses' response regarding the role that the community nurse is and should be playing on health committees}

The majority, that is, twenty out of thirty-eight of the community nursing respondents had attended three or fewer health committee meetings over a period of two years when meetings were launched and were therefore familiar with health committees. On average, meetings were held every second month.

All 38 respondents agreed that health inspectors, doctors, social workers and teachers should also serve on health committees to facilitate inter-disciplinary interaction. The other principle namely that of inter-sectoral co-operation was answered positively by $94,7 \%$ of the respondents. One respondent said that other disciplines such as water affairs, environment and housing should have been included in the health

\section{Table 1 : Number of meetings attended by Community nurse respondents}

\begin{tabular}{|l|c|c|}
\hline NUMBER OF MEETINGS & MEETINGS & PERCENT AGE \\
\hline$>20$ & 3 & 8 \\
\hline $15-20$ & 3 & 8 \\
\hline $8-15$ & 5 & 13 \\
\hline $4-8$ & 4 & 10 \\
\hline $1-\mathrm{m}^{3}$ & 10 & 26 \\
\hline NIL & 10 & 26 \\
\hline NO RESPONSE & 4 & 10 \\
\hline TOTAL & 38 & 100 \\
\hline
\end{tabular}

\section{Health Committees}

Health committees consist of voluntarily organized groups, elected by the community, backed by health professionals and communicators based at health centres. They identify, plan and implement projects and educate the community in which they function. The health committees participate with and committees. Her experience however was that they had not been included in health committees.

Forty-five percent of the respondents were involved with their health committees, although few were attending meetings. It was reported that some clinics had a community nurse representative who liaised between the health committee and the community nurses. The meeting times were inconvenient for 
$53 \%$ of the respondents. Fifty-three percent responded that they were expected to attend meetings after hours. One respondent said that meetings were missed because of dangerous situations. Seventy-one percent indicated that health committees meetings were not held at a convenient time for respondents to attend. Twenty-nine percent responded that times were convenient for them. A meeting on a weekend was suggested by one respondent. Some workers were unable to attend meetings because of workload and others experienced danger and lack of transport. Sixty-one percent responded that management did encourage respondents to attend meetings but the community nurses did not attend.

The question about whether health committees should be involved with policy making, problem solving and handling of complaints at the clinics was reflected positively by $45 \%$ of respondents. Thirty-eight percent did not know whether they should be involved. Thirty-four percent of respondents said health committees were consulted when changes occur in lo- were unanswered. Functions including community involvement, group work, community mobilization, community development and health committee involvement were understood to be a part of the job descriptions of a community nurse by $71 \%$ of the respondents. Twenty-nine percent indicated that these were not part of their role. Training for these functions had been received by $57 \%$ of the respondents. Some of the respondents indicated that what they were doing was self taught.

\section{Training for community work}

Fifty-seven percent of the respondents had received training regarding community involvement, group work, community mobilization, community development and health committees. Forty-one percent of the respondents indicated that they had not received the training. Community mobilization and health committee involvement were the two skills needing most attention. The two questions on self evaluation of competency skills concerning identifying local community needs

\section{Figure 1: Involvement with health} committees

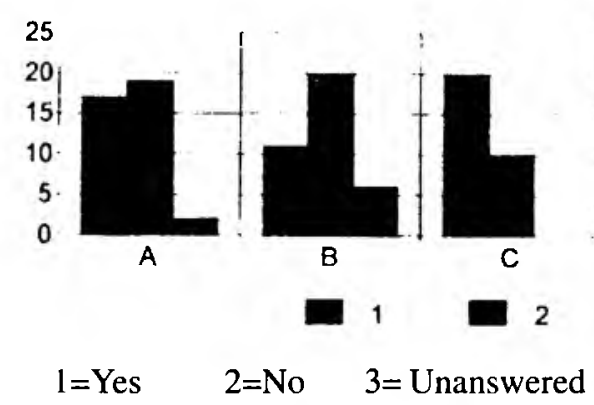

$\mathrm{A}=$ Are you involved with health committees?

$\mathrm{B}=$ Are meeting times convenient?

$\mathrm{C}=$ Are you expected to attend health committee meetings after-hours?

$\mathrm{D}=$ Does management encourage you to attend health committee meetings?

$\mathrm{E}=$ Are health committee meetings regarded as extra mural activities?

cal healthy policy. Eleven percent said that they were not consulted and 55\% did not know. Twenty one percent of the respondents said that health committees were consulted when problems occur concerning health in their area; $13 \%$ of respondents said health committees were not consulted, and $39 \%$ did not know. Fifty-eight percent of community nurses said that health committees are involved when complaints were made about the health clinic; $21 \%$ said no and $21 \%$ did not know.

\section{Structures in place for community contributions}

The question on whether structures were in place to allow the community to contribute suggestions to improve health care was answered in the affirmative by $47 \%$ of the participants. Thirteen percent did not know if these structures existed, while $34 \%$ said there were no structures and $5 \%$ of the questions

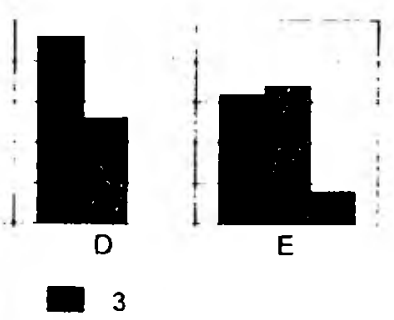

and prioritizing of community needs have been grouped and $82,5 \%$ of the respondents felt capable in the execution of these functions.

Sixty percent of the respondents indicated that they knew how to mobilize support in the community, and were well acquainted with the community resources and important backup people in the community. "Very well", was the response of $32 \%$ of the community nurses. "Well", was the response of $60 \%$ of the respondents. "Poor" was the response of $12 \%$ of the respondents.

\section{Beliefs of community nurses}

Ninety-seven percent of the community nurses acknowledged they had a responsibility for initiating change in the community. The majority of respondents believed they, as professionals, would be able to influence and change situations through groups and personal influence. The question of community participation as a strategy for health care, communities being asked to contribute to planning, co-ordination and monitoring health care were endorsed by $100 \%$ of the respondents. One hundred percent of the community nurses believed that communities should be asked to make decisions about their own health needs. All the respondents believed they had a function in reforming health care and serving on health committees. 


\section{Collaboration between the community and community nurse}

A question on collaboration between the community and the community nurse was answered positively by $63 \%$ of the respondents. The question on collaboration between the community and the clinic was answered positively by $68 \%$ of the respondents, although one respondent said that interaction between the clinic and the community was good because the health committee ensured it. The question on whether the consumers of health care need education in identifying health needs, prioritizing health needs and involving themselves on health committees, was answered positively by $96 \%$ of the respondents.

\section{The role of the community nurse on health committees}

These were the roles that received the highest scores from the community nurses. This is reflected in the above chart. The community nurses were aware of what their role was on health committees although very few were actively involved.

\section{The community nurse as a resource person}

The community nurses' medical knowledge was viewed as important by all the respondents. The community nurses were identified as resource people for the community, to help with health education. One respondent said that because of the community nurses' knowledge about educational facilities and organizing seminars, they were identified as health educators of the community.

\section{The community nurse as a professional person}

All the respondents mentioned that community nurses had a professional role to play on health committees. The professional role revolved around their knowledge of "hands on experience". Two cited the main reasons for the professional roles, as their nursing background and their close proximity

\section{Figure 2 : The role of the community nurse on health committees}

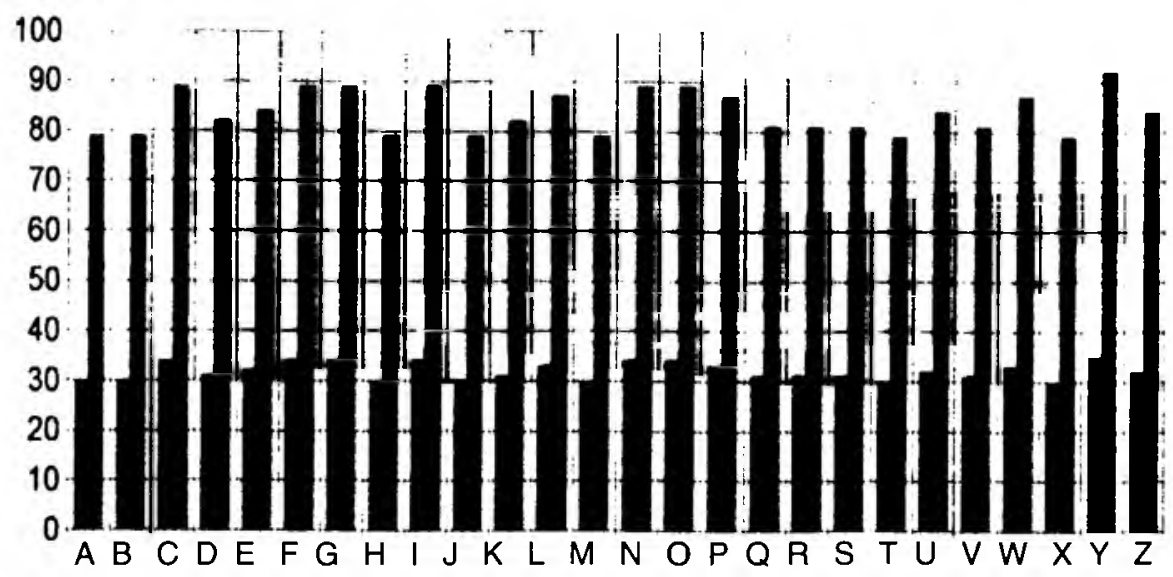

$(\mathrm{N}=38)$ Red - response Green - Percentage

KEY:

$\mathrm{A}=$ Care provider

$\mathrm{B}=$ Motivator

$\mathrm{C}=$ Communicator

$\mathrm{D}=$ Encourager

$\mathrm{E}=$ Having good interpersonal skills

$\mathrm{F}=$ Listen with respect

$\mathrm{G}=$ Respect others opinions

$\mathrm{H}=$ Show Sensitivity

$\mathrm{I}=$ Assisting in decision-making

$\mathrm{J}=\quad$ Mobilizer of the community

$\mathrm{K}=$ Mediator

$\mathrm{L}=$ Facilitator of Change

$\mathbf{M}=$ Planner of Objectives

\section{Health committee members' response} regarding the role that the community nurse is and should be playing on health

\section{committees}

The following categories were identified from data obtained from the individual interviews with members of the health committees:
$\mathrm{N}=$ Liaison Person

$\mathrm{O}=$ Encourager of the need to change

$P=$ Identifier of needs

$\mathrm{Q}=$ Negotiator

$\mathbf{R}=$ Help structure a group

$\mathrm{S}=$ Guider of the group

$\mathrm{T}=$ Resource provider

$\mathrm{U}=$ Community Organiser

$\mathrm{V}=$ Empowerer of people

$\mathrm{W}=$ Interpreter of information

$\mathrm{X}=$ Expert of Health

$\mathrm{Y}=$ Educator

$\mathrm{Z}=$ Interpreter of meanings

to the community, with their first hand knowledge of health situations experienced in the area. Two responded that the community nurses' awareness of "trends of illness" in the area, and the community nurses' awareness of health problems were important aspects of the function, and two more mentioned their "hands on" experience with health problems in their community as being important. Three believed the functions of the community nurse as being that of "guide and to direct the committee" on health matters. 
All the respondents agreed that the community nurses had an interpersonal collaborative role to play, both with their colleagues and the community. Three mentioned the community health nurses as linking the committee, the community and the health authority.

Qualities identified with the community nurses' interpersonal coliaborative role:

- One respondent commented that "when they are in the health forums they should talk positively and not negatively".

- The community nurses have to deal with the commu -nity and be available for the community, "you could be called out at any time"; "the community must know they can go straight to you".

- The community nurses must work with other people and be "able to deal, even with difficult people", was said by one respondent.

- $\quad$ The community nurse must accept that the commu -nity "may not be well learned, but they know their needs", was indicated by one respondent.

- One respondent commented that the community nurse "should not be aloof in their approach", but, need to know how to "go to their level, and respect the peo -ple".

\section{Leadership role of the community nurse}

All the respondents agreed that the community nurses had a leadership role, both in the committee and the community. One respondent identified the community nurses as having "natural or learned leadership qualities". With the community nurses' health knowledge they should be able to "contribute to facilitate the health budget and improve health in the area". Another respondent indicate that the community nurse should "lead by example".

\section{Planning role of the community nurse}

There was consensus that the community nurse had a planning role to play, one committee having a community nurse in the forefront of planning and community organization. Another respondent indicated that the whole committee should be involved in health care planning, but this included the community nurse. One respondent mentioned that "she's got to be part of the planning of the whole thing".

\section{Co-ordination role of the community nurse}

All agreed that the community nurses had a vital co-ordination role to play. Involving all the relevant role-players and drawing them into the structure of the health committee was identified as the role of the community nurse.

\section{- Committee co-ordination}

One respondent indicated that the community nurse holds the health committee together, by "following up on decisions, making all parties aware of meetings, and she works well with other community leaders". The function of following up on decisions made at the committee meetings came through very strongly as being the responsibility of the community nurse, this was mentioned by two respondents. "Her awareness of the existence of the committee, and using her com munity contacts, the community nurse made her com munity aware of the existence of the health commit -tee", was said by one respondent. Another said the community nurse "contributed professionally in the coordination of the health sub-committees".

One respondent mentioned that the community nurse was the only one the committee had any interplay with; "the higher guys have not got enough time or they have not got enough interest in the actual running of the committees".

\section{- Community co-ordination}

Two respondents, viewed the role of the community nurse as the link between the community and the health authorities as important. One respondent said that the community nurse worked well with community lead -ers. The community nurses were viewed by one re -spondent as "playing a very good co-ordination role even in the local public sectors", e.g. centres for the homeless. One respondent said "not be a lone ranger having all your ideas without consulting other people .... so this is the role that I see the nurses can play".

\section{Educational role of the community nurse}

Health education was viewed by all the respondents as an important role of the community nurse, both on the health committee, and in the community. Three respondents viewed the community nurses' role on the committee as being to guide and direct the health committees in this regard, "as the committee was not always knowledgeable enough about health matters". Two respondents mentioned the community nurses' "awareness of health trends", as being part of their professional role, but this was part of education as well, as she would be the one to alert them to, and make them aware of what is happening in their community. The educational role of the community nurse on the health committee appeared to focus on aspects concerning drugs, according to two respondents.

\section{Main conclusion}

No doubt exist that the community nurse should participate in health committee meetings. There were however factors identified that hinder her from participating.

A significant correlation was found between the viewpoints of the community nursing respondents and the health committee members regarding the role that community nurse is and should be playing on health committees. This also correlated with the literature study. This data was utilised in order to write some guidelines that the community nurse can follow during the execution of his/her role in health committees.

The following aspects regarding the role of the community nurse in health committees are recommended namely that: 
Management should facilitate the attendance of health committee meetings by community nurses. Sufficient infra-structure should be created to enable the com -munity nurse to be involved on health committees. The community nurse has a significant role to play regard -ing initiation, co-ordination, and facilitation in the health related fields in the community.

Nursing service managers need to ensure that these functions are included in updated job descriptions and that relevant in-service training is implemented to ensure that the community nurses are aware of their functions and are equipped with the relevant knowl -edge to carry out the above

\section{Guidelines as to the role of the community nurse on health committees}

The community nurse should:

Take the initiative and ensure that health committees are created in areas where they do not exist. When involved with health committees, facilitation and coordination of these health committees is part of his/ her responsibility.

Facilitate and co-ordinate the health committee on behalf of the community. He/she should draw in pro -fessional people such as doctors, health inspectors, social workers and other medical and paramedical per -sonnel who should be encouraged to serve on health committees. Teachers and other lay people including politicians, church leaders, priests, sangomas and herbalists should also be invited. The health commit -tee needs to develop into a multi disciplinary and inter-sectoral health committee.

As the undisputed leader of the primary health care team the community nurse was found to be the person to take leadership and be involved in policymaking in health context. Therefore he/she should:

Act as the leader of the primary health care team and must ensure that new policy and legislation regarding health committees and health care delivery is well known to him/her and the health committee.

Ensure that the health committee is alerted that health policy changes have been introduced. He/she must ensure that problems and complaints at the local health facility are jointly solved by the health authority and the health committee. He/she must encourage the de -velopment of structures to enable the community to contribute suggestions and ideas to improve health care in the area.

Be guided by his/her job description which should in -clude community involvement, group work, commu -nity mobilization, community development, identify -ing health needs, prioritizing health needs and in -volvement on health committees. .

Accept the responsibility to be a resource person for the health committee. They have the health knowl -edge as well as being aware of the facilities avail -able in the area they work in. They know key role players via their work and must have the ability to evaluate situations and refer queries appropriately so that the members of the community are helped with out delay.

\begin{abstract}
Initiate change in health care in South Africa through active and continuous involvement on health committees. The community nurse needs to know how to analyze the impact of health policy changes on a community, and learn about strategies for implementing change.
\end{abstract}

Involve the community with decisions about the com -munities health care and needs. The community should be involved with planning, co-ordination and monitoring health care. The community nurse needs to ensure that this is happening by providing struc -tures within health committees and being involved on health committees.
Ensure that there is collaboration between the com -munity and themselves as well as between the com -munity and the clinic which is the local health serv -ice provider.

The most significant role that the community nurse is and should be playing in the community is that of educator and he/she should:

Accept the responsibility to educate the consumers of health who are the community. The community nurse needs to empower the members of the community with information about health care, health care delivery and services, including how to identify health needs in the community and how to prioritize the identified needs.

Finally it was concluded from the data gathered and analysed in this study that the community nurse is and should be playing the following roles:

A professional role on health committees. He/she should be a care provider, advocating on behalf of the community, providing a professional evaluation of various situations and playing a counselling and con -sultant role on the health committee.

An interpersonal collaboration role on health com
-mittees. He/she need to have good interpersonal
skills, listen to people with respect, respect other peo
-ple's opinions, show sensitivity and be able to com
-municate well. He/she must encourage others, stimu
-late the members of the health committee and be able 
to meet logical demands that the health committee make of him/her.

A leadership role on health committees, encouraging the participants to be involved. The community nurse must not be in charge of the health committee but sup -port the selected or elected leader of the group. $\mathrm{Hel}$ she must help the health committees in decision-mak -ing and the implementing of new ideas. He/she must act as a mediator and help mobilize the community. The leadership role of the community nurse must fit in with the community development model. He/she must provide a leadership role within the health commit -tee, prompting them, directing them, encouraging them to carry out the projects the health committee has identified. The responsibility should not be taken away from the community or health committee mem -bers. He/she must provide a complimentary leader -ship input for the health committee.

\begin{abstract}
A planning role on health committees. He/she must act as a liaison person, encourage the need for change when it arises, help design strategies for change when it arises and help facilitate change when it occurs. A co-ordination role on health committees. He/she act as a community organizer, helps structure the group and will hereby empower people. He/she must negoti -ate, co-ordinate and identify resources for the health committee.
\end{abstract}

An education role on health committees. He/she is regarded as knowledgeable on health matters by the health committee and must interpret information and meanings of health information for the health com mittee, sharing his/her knowledge with them.

Guidelines should be operationalised and implemented to improve this aspect of community nursing practice. Recommendations are made based on the data obtained in the study with reference to nursing practice, nursing education and nursing research.

\section{Nursing Practice}

The guidelines can be operationalised to enable he community nurse to function on health committees as he/she should be. This will improve the practice of nursing and contribute positively to the health committees.

\section{Nursing Education}

The guidelines can be included in the undergraduate and post basic nursing curriculum so as to ensure that the community nurse is better equipped to function on a health committee and that all role players are aware of their responsibility. In service training will be necessary for those community nurses already qualified.

\section{Nursing Research}

Guidelines could be adapted and tested in other areas avoiding a full replication study. As this is a contextual study, these results apply only to the local authority concerned. Replication research needs to be done, as similar problems could be encountered in other areas. Community nurses must have enough resources to do research, that is time, sponsorship, encouragement and co-operation.

\section{Concluding statement}

Health Committees are necessary in South African communities. The community nurse has a significant role to play on these health committees. This viewpoint was shared by health committee members. The community nurse is comprehensively trained to make him/a valuable member of these committees. She is the most suitable person in the health team to act as a liaison person between the community and other members of the inter-disciplinary health team and intersectoral team. Her role should be the subtle guidance in health committees and not a prominent leadership role. That should be left to a member of the community.

\section{References}

AFRICAN NATIONAL CONGRESS 1994: The reconstruction and development programme. Johannesburg: Umyano Publications.

AFRICAN NATIONAL CONGRESS 1994: The African National Congress health policy for South Africa. Johannesburg: Umyano Publications.

BARNES; ERIBES, E; JUARBE, C; NELSON, T; PROCTOR, M; SAWER, S; SHAUL, L \& MELEIS, M 1994: A Primary care: a confusion of philosophies. Nursing Outlook. 43 (1) Jan/Feb 1994:7-14.

DENNILL, K; KING, L; LOCK, M \& SWANEPOEL, T 1995: Aspects of primary health care. Southern Book Publishers (Pty) Ltd: Half Way House.

FERRINHO, P; ROBB, D; CORNIELJE, H \& REX, G 1993: Primary Health Care in Support of Community Development. WHO Forum. 14(1): 1993: 14-18. 
OERMANN, M 1994: Reforming nursing - education for future practice. Journal of Nursing Education. 33(1) Jan 1994:215219.

OWEN, CP 1995: A policy for the development of a district health system for South Africa. Department of Health.

PICK, W 1993: Alternative strategies for the delivery of health care in South Africa. Social Work. 14 (3) Jan 1990:223-228.

POGGENPOEL, M 1996: Promoting nurses mental health. Health SA Gesondheid. 1 (2) 1996:12-15.

POGGENPOEL, M \& MULLER, M 1996: Challenges facing the SA nursing profession - "People driven health system. Health SA Gesondheid. 1 (1) 1996:10-13.

SAWYER, 1 1995: Community participation: lip service? Nursing Outlook. 43 (1) Jan/Feb. 1995: 11-18.

SMITH, G 1979: Social work and the sociology of organizations - Revised edition. Routledge \& Kegan Paul: London.

SOUTH AFRICAN NURSING COUNCIL: Standards for nursing practice. Pretoria: SANC.

STANHOPE, M \& LANCASTER, J 1992: Community Health Nursing. Process and Practice for Promoting Health. Mosby: USA.

TROFINO, J 1997: The courage to change. Nursing Management. 28 (11) Nov 1997.

VAUGHN, B 1997: Teaching nurses to think boldly in a time of crisis. International Nursing Review. 44 (6) Issue 366 Nov/ Dec 1997.

WHITE PAPER, 1997: Transformation of the Health System in South Africa. Cape 